
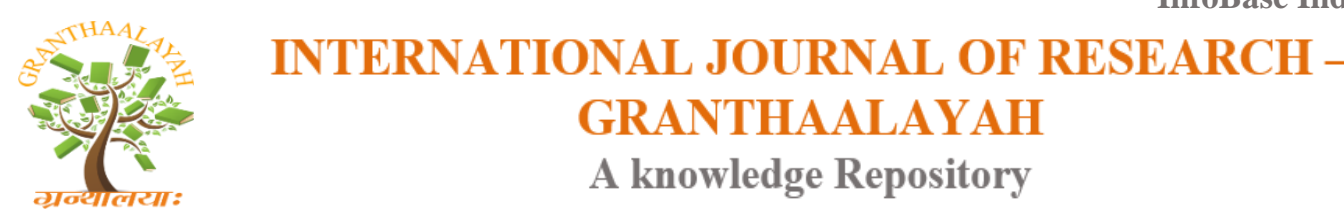

Management

\title{
EFFECT OF CUSTOMERS' DEMOGRAPHICS ON RETAIL FORMAT CHOICE AND INTERACTION: A STUDY ON RETAIL SECTOR IN INDIA
}

\author{
Dr. Pankaj Kumar *1 \\ ${ }^{*}$ Assistant Professor, Department of Management Studies, Deenbandhu Chhotu Ram University \\ of Science \& Technology, Murthal, Sonipat, Haryana, India
}

DOI: https://doi.org/10.29121/granthaalayah.v5.i1.2017.1906

\begin{abstract}
The purpose of the study is to examine how often customers interact with different types of retail formats. A structured questionnaire was successfully distributed to 600 respondents, who had made purchases from sixty retail formats operated in Delhi and Gurugram belonging to the domain of Shopping Malls, Hypermarket, Supermarket, Department Stores, Discount stores and Category Killers through systematic stratified sampling for the collection of data. To segment the customer groups for each of the four retail formats (shopping mall, supermarket, department store, and category killer) based on demographic variables (gender, age, marital status, occupation, and income), a two-way ANOVA was used on the shopping frequency of the respondents. The Chi-square $\left(\chi^{2}\right)$ test was also used to test the significant differences in shopping motives, companion during their visit, whether a planned or unplanned shopping trip, the staying time in a retail format of the respondents based on their gender and age. The study found that gender and age, gender and occupation, and gender and education are more or less equally important factors, whereas gender and marital status, and gender and income were not found important factors in affecting store visits. The study also found the behavioral aspect of retail customers in many ways. First, their visits to the stores were primarily driven by purchase needs, either window shopping or making actual purchases followed by eating. Second, more people prefer to visit these stores along with their friends or family; this result contributes to that being accompanied by others (Companion), shoppers more likely to buy food and less likely to buy non-food products.
\end{abstract}

Keywords: Demographics; Retail Formats; Customers' Interaction; Shopping Motives; India.

Cite This Article: Dr. Pankaj Kumar. (2017). "EFFECT OF CUSTOMERS' DEMOGRAPHICS ON RETAIL FORMAT CHOICE AND INTERACTION: A STUDY ON RETAIL SECTOR IN INDIA." International Journal of Research - Granthaalayah, 5(1), 316-331. https://doi.org/10.29121/granthaalayah.v5.11.2017.1906. 


\section{Introduction}

With an estimated population of 1.31 billion, India is the world's second most populous country after the People's Republic of China and represents almost 17.31 per cent of the world's population, which means one out of six people on this planet lives in India. More than 50 per cent of India's current population is below the age of 25 and over 65 per cent below the age of 35 (India's Population, 2016). Furthermore favourable changes in the socio-economic and demographic arenas also increase the growth of retail sector in India, and Indians' disposable incomes are increasing, allowing them to spend more and try new products, brands, and categories while spending a lower proportion on food and customers prefer to shop at organized retail formats wherein they can get food \& grocery, electronics items, apparel \& footwear, fashion accessories, entertainment and all other things they want to shop under one roof, for the reason of saving their time, efforts and avoid expenses. Organized retailing is witnessing a wave of players entering in the retail industry. These players are experimenting with various retail formats ranging from beauty and health stores, supermarkets, hypermarket, self-service music stores, to new age book stores, ordinary low price stores, computers and peripherals stores, office equipment stores and home/building construction stores. Changes in the socio-economic and demographic variables of customers effect massively to the growth of retail stores formats. In order to achieve the goal of retailers, it is important to address the basic query that who are your shopping prone customers? Understanding of this question will help to retailers to target the appropriate customers and guide their marketing plans and strategies for target segment. Interestingly, the question of "who are the retail store formats customers" has been a long studied in the marketing literature, yet not answered completely and studies on shopper behaviour in India have been limited in the context of demographic profile and their time \& money spending pattern towards a particular format of retail store (Sinha, 2003), and shopper's decision to choose "where to shop" varies largely across retail formats (Fox et al., 2004). This study examines the relationship between customers' demographics and their interaction towards different types of store formats choice decisions in retailing in India. After the reviewing of existing literature, it is found that most of the studies on retail sector are reported from developed countries and no studies were identified that evaluate the effect of customers' demographics on their interaction with retail formats in India, so this study aims to fill in this gap and will help to understand that "who are the repeatedly customers of retail formats and their store choices pattern in Indian retailing context" and what are their motives of shopping towards in retail stores based on (gender and age).

\section{Review of Literature}

Customers' demographical factors such as gender, age, education, marital status, occupation, income and family size massively influence the choice of retail format in grocery retailing (Bellenger and Korgaonkar, 1980; Bawa and Ghosh, 1999; Fox et al., 2004; Carpenter and Moore, 2006). Stone (1995) did the comparision of demographical profile of warehouse club shoppers and super centres shoppers and exposed that the shoppers of warehouse club are young; more educated and have high income level. Fox et al. (2004) investigated the effect of demographics factors on the behaviour of retail customers' decision towards grocery stores, mass merchandisers, and drug stores and found the weak relationship between education, income, family size and retail store choice moreover customers' demographics influence his sensitivity 
towards pricing of the products, which in turn influence his choice of store. Prasad and Aryasri (2011) studied the effect of shoppers attributes on retail format choice behaviour for food and grocery retailing in India and found the significant relationship between customers' demographics and retail format choice decisions. Customers' demographics such as gender, age, education, occupation, income and family size except marital status significantly influence retail format choice decisions of customers in food and grocery retailing in India, so it seems that consumers who are younger, educated and higher incomes have greater patronages towards modern grocery formats. Guidry and Montero (2005) resulted that over 70 per cent of customers who visited a lifestyle centre make a specific purchase rather than to browse and window shopping and the enjoyment of male shoppers have been influenced by the environmental attributes of shopping centres (Lee et al., 2005). Carpenter (2008) concluded that the involvements of female customers are more often in health and beauty products than male customers in shopping at super centre, while the involvements of male customers are more often in electronics products than female customers, moreover study found that the customers' demographics (age, education, occupation, income and family size) are significant for home furnishing, consumer electronics, and apparel. For apparel segment age and incomes showed inverse relationship to shopping frequency of customers, whereas the size of family shows direct relationship for selection of apparel products store. Furthermore age found significant but inverse relationship in the segment of home furnishing shopping frequency at super centre. For consumer electronics segment demographics factors such as age and education also showed inverse relationship to shopping frequency at super centre. So result of the study as whole shows that the age factor appears particularly promising and demonstrating significance in three out of the four products segment and generally appears that younger customers take advantage of the shopping under one roof provided by super centers.

\subsection{Conceptual formation}

Based on the reviewed of marketing literature on retail customers' demographics, their shopping frequency and store visit motives with various retail formats the conceptual framework of this study preliminary consisted of two sections: the first section concerning with shopping frequency of the respondents in four types of retail formats (Shopping Malls, Supermarket, Department Stores, and Category Killers) based on their demographic variables (gender, age, marital status, occupation, and income) and second section covered the retail customers' shopping motives, companions, planned or unplanned shopping trips, visiting frequency to a particular retail format, and length of stay for shopping in a particular retail store/format related variables to segment customer groups. For the purpose of the study of this section, a set of seven questions comprising of general aspects including four items for 'retail formats visited in the last three months'; six items for 'main reason to visit the retail format', three items for 'companion during visit to the retail format', two items for 'planned or unplanned shopping trip', three items for 'retail format visit frequency' and three items for 'time spent in the retail format' have been analyzed. The main emphasis of the present study is to examine how often customers interact with different types of retail stores. Confirming the reviewed findings of prior researches, a set of 10 null hypotheses was developed which is shown in table-1. 
Table 1: Hypotheses

$\mathbf{H}_{1 \mathbf{a}}$ : There is no association between shopping frequency in retail formats of customers based on their gender and age.

$\mathbf{H}_{1 \mathbf{b}}$ : There is no association between shopping frequency of customers based on their gender and age in four types of retail formats.

$\mathbf{H}_{\mathbf{2} \mathbf{a}}$ : There is no association between shopping frequency in retail formats of customers based on their gender and marital status.

$\mathbf{H}_{\mathbf{2 b}}$ : There is no association between shopping frequency of customers based on their gender and marital status in four types of retail formats.

$\mathbf{H}_{\mathbf{3}}$ : There is no association between shopping frequency in retail formats of customers based on their gender and occupation

$\mathbf{H}_{\mathbf{3 b}}$ : There is no association between shopping frequency of customers based on their gender and occupation in four types of retail formats.

$\mathbf{H}_{\mathbf{4}}$ : There is no association between shopping frequency in retail formats of customers based on their gender and education.

$\mathbf{H}_{\mathbf{4 b}}$ : There is no association between shopping frequency of customers based on their gender and education in four types of retail formats.

$\mathbf{H}_{\mathbf{5 a}}$ : There is no association between shopping frequency in retail formats of customers based on their gender and income.

$\mathbf{H}_{\mathbf{5 b}}$ : There is no association between shopping frequency of customers based on their gender and income in four types of retail formats.

\section{Materials and Methods}

The purpose of the study is to examine how often customers interact with different types of retail store formats. A structured questionnaire was successfully distributed to 600 respondents, who had made purchases from sixty retail formats operated in Delhi and Gurugram belonging to the domain of Shopping Malls, Hypermarket, Supermarket, Department Stores, Discount stores and Category Killers through systematic stratified sampling for the collection of data, reason being Delhi and Gurugram as the area has a high migrated and heterogeneous residents with various dimensions such as religious, caste, traditions, social hierarchy, language, literacy, education, occupation and income etc. Out of 600 distributed questionnaires, 461 questionnaires were filled by respondents, 84 incomplete questionnaires were not used for analysis and 377 questionnaires were valid ones; thus the effective recovery rate was 62.83 per cent and respondents were personally administered. SPSS (Version17.0) was used for analysis in this study. Internal consistency analysis was used to access the reliability of measurements. Cronbach's $\alpha$-value is commonly used for this purpose and $\alpha$-value must be higher than 0.70 (Nunnally, 1978). To segment the consumer groups for each of the four retail formats (shopping mall, supermarket, department store, and category killer) based on demographic variables (gender, age, marital status, occupation, and income), a two-way ANOVA was used on the shopping frequency of the respondents. The Chi-square $\left(\chi^{2}\right)$ test was also used to test the significant differences in shopping motives, companion during their visit, whether a planned or unplanned shopping trip, the staying time in a retail format of the respondents based on their gender and age. 


\subsection{Internal Consistency Analysis}

Internal consistency was used to assess the reliability of the measurements (six constructs) depicting the degree to which they indicate a common latent (unobserved) construct. Description of the variables $\left(\mathrm{V}_{1}\right.$ to $\left.\mathrm{V}_{6}\right)$ those used in the study are shown in table- 2 .

Table 2: Description of the buyer behaviour stimuli related variables with internal consistency results

\begin{tabular}{|l|l|l|l|}
\hline Variable No. & Description of & $\begin{array}{l}\text { No. } \\
\text { items/statements }\end{array}$ & $\begin{array}{l}\text { Cronbach's } \\
\text { Alpha }\end{array}$ \\
\hline $\mathrm{V}_{1}$ & $\begin{array}{l}\text { Shopping frequency in last three } \\
\text { months }\end{array}$ & 04 & 0.8917 \\
\hline $\mathrm{V}_{2}$ & Reasons to visit the retail store & 06 & 0.8241 \\
\hline $\mathrm{V}_{3}$ & Companion during the store visit & 03 & 0.7826 \\
\hline $\mathrm{V}_{4}$ & Planned or unplanned shopping trip & 02 & 0.8345 \\
\hline $\mathrm{V}_{5}$ & Store visiting frequency & 03 & 0.7462 \\
\hline $\mathrm{V}_{6}$ & Length of stay & 03 & 0.8308 \\
\hline
\end{tabular}

The alpha values range from 0.7462 to 0.8917 , which indicates an internal consistency with the alpha value of more than 0.70 , so no items were dropped from above list. These results are therefore acceptable and are a reliable measure of the constructs. Overall, this section of the instrument has been proven to be an acceptable instrument through this test.

\subsection{Descriptive Statistic}

Table- 3 shows that from a total of 377 respondents, the representation was noted higher of male respondents (54.11 per cent), who were married (35.81 per cent), Bachelor degree (22.81 per cent), in the age group of 25-35 years (26 per cent) and 36-45 years (15.12 per cent), belonging to salaried class (28.65 per cent) and earn more than Rupees 10 lakhs (22.55 per cent) being surveyed from the premises of malls (11.94 per cent), department Stores (5.57 per cent), discount Stores (8.49 per cent) and category Killer Stores (11.41 per cent) as compared to their female counterparts under study. On the other side, female representation was slightly higher of those holding master degree or above (25.20 per cent), within an annual income group of Rupees 5-10 lakhs (18.04 per cent) and who participated from the premises of Hypermarkets (10.34 per cent) or Supermarkets (9.55 per cent) in the survey.

Table 3: Retail Formats-wise Distribution of Surveyed Customers and their Demographic Profile

\begin{tabular}{|l|l|l|l|l|}
\hline \multicolumn{2}{|l|}{ Basic Classification } & \multicolumn{3}{l|}{ Numbers of Respondents (Percentage) } \\
\cline { 3 - 5 } & Male & Female & Total (N=377) \\
\hline \multirow{3}{*}{$\begin{array}{l}\text { Formats of } \\
\text { Retail Store }\end{array}$} & Malls & $45(11.94)$ & $34(9.01)$ & $79(20.95)$ \\
\cline { 2 - 5 } & Hypermarket & $33(8.75)$ & $39(10.34)$ & $72(19.10)$ \\
\cline { 2 - 5 } & Supermarket & $30(7.96)$ & $36(9.55)$ & $66(17.51)$ \\
\hline \hline
\end{tabular}




\begin{tabular}{|c|c|c|c|c|}
\hline & Department Store & $21(5.57)$ & $19(5.04)$ & $40(10.61)$ \\
\hline & Discount Store & $32(8.49)$ & $15(3.98)$ & $47(12.47)$ \\
\hline & Category Killers & $43(11.41)$ & $30(7.96)$ & $73(19.36)$ \\
\hline & $<25$ years & $21(5.57)$ & $23(6.10)$ & $44(11.67)$ \\
\hline$\Delta \sim$ & 25-35 Years & $98(26.00)$ & $65(17.24)$ & $163(43.24)$ \\
\hline Age & 36-45 Years & $57(15.12)$ & $49(13.00)$ & $106(28.12)$ \\
\hline & $>45$ Years & $28(7.42)$ & $36(9.55)$ & $64(16.97)$ \\
\hline & Diploma or below & $31(8.22)$ & $11(2.92)$ & $42(11.14)$ \\
\hline Highest Level & Bachelor Degree & $86(22.81)$ & $67(17.80)$ & $153(40.57)$ \\
\hline & $\begin{array}{l}\text { Master Degree or } \\
\text { above }\end{array}$ & $87(23.08)$ & $95(25.20)$ & $182(48.28)$ \\
\hline Marital Status & Single & $69(18.30)$ & $56(14.85)$ & $125(33.16)$ \\
\hline vrantal status & Married & $135(35.81)$ & $117(31.04)$ & $252(66.84)$ \\
\hline & Student & $17(4.51)$ & $06(1.59)$ & $23(6.10)$ \\
\hline Orounation & Housewife & $0(0.0)$ & $18(4.77)$ & $18(4.77)$ \\
\hline uccupation & Salaried & $108(28.65)$ & $101(26.79)$ & $209(55.44)$ \\
\hline & Self-Business & $79(20.95)$ & $48(12.73)$ & 127 (33.69) \\
\hline & $<$ Rupees 5 lakhs & $52(13.79)$ & $57(15.12)$ & $109(28.91)$ \\
\hline $\begin{array}{l}\text { Annual Income } \\
\text { (In Runees) }\end{array}$ & Rupees 5-10 lakhs & $67(17.77)$ & $68(18.04)$ & $135(35.81)$ \\
\hline & > Rupees 10 lakhs & $85(22.55)$ & $48(12.73)$ & $133(35.29)$ \\
\hline Total $(\mathrm{N}=377)$ & & $204(54.11)$ & $173(45.89)$ & $377(100)$ \\
\hline
\end{tabular}

Furthermore, out of 377 respondents, 20.95 per cent from the premises of Shopping Malls, 19.36 per cent from Category Killers, 19.10 per cent from Hypermarkets, 17.51 per cent from Supermarkets, 12.47 per cent from Discount Stores and 10.61 per cent from Department Stores, were the participants in the final survey.

\section{Results and Discussions}

\section{Customers' Interaction with Different Type of Retail Formats:}

To analyze how often customers interact with different type of retail stores, the study examined the shopping frequency of the respondents in four type of retail formats (Shopping Mall, Supermarket, Department Store, and Category Killer) based on their demographic variables (gender, age, marital status, occupation, and income), their shopping motives, companions, planned or unplanned shopping trips, visiting frequency to a particular retail format and length of stay for shopping in a particular retail store/format related variables to segment consumer groups. 
4.1.Segmentation Based on Gender, Age and Retail Format

Table 4: Cross-tabulation of Shopping Frequency by Gender and Age (N=377)

\begin{tabular}{|c|c|c|c|c|c|c|}
\hline Gender and Age & $\begin{array}{l}\text { Shopping } \\
\text { Mall }\end{array}$ & Supermarket & $\begin{array}{l}\text { Department } \\
\text { Store }\end{array}$ & $\begin{array}{l}\text { Category } \\
\text { Killer }\end{array}$ & F Value & p value \\
\hline \multicolumn{5}{|l|}{ Male } & & \\
\hline$<25$ years & 18 & 3 & 11 & 12 & & \\
\hline 25-35 Years & 62 & 48 & 39 & 68 & & \\
\hline 36-45 Years & 42 & 29 & 41 & 38 & & \\
\hline$>45$ Years & 12 & 18 & 8 & 7 & & \\
\hline \multicolumn{5}{|l|}{$F_{\text {row }}(3,9)$} & 28.677 & $0.000 * *$ \\
\hline$F_{\text {column }}(3,9)$ & & & & & 1.324 & 0.326 \\
\hline \multicolumn{5}{|l|}{ Female } & & \\
\hline$<25$ years & 16 & 6 & 10 & 11 & & \\
\hline 25-35 Years & 52 & 34 & 47 & 54 & & \\
\hline 36-45 Years & 33 & 16 & 36 & 27 & & \\
\hline$>45$ Years & 14 & 18 & 26 & 14 & & \\
\hline \multicolumn{5}{|l|}{$F_{\text {row }}(3,9)$} & 28.188 & $0.000 * *$ \\
\hline \multicolumn{5}{|l|}{$F_{\text {column }}(3,9)$} & 3.009 & 0.087 \\
\hline
\end{tabular}

Annotations: $* \mathrm{p} \leq .05 ; * * \mathrm{p} \leq .01$; and $\mathrm{N}=$ Number of respondents

Table-4 shows the frequency of respondents visiting various type of stores by gender and age. Two-way ANOVA was performed to test the hypothesis whether the pattern of the respondents' store visits depended on demographic variables, gender and age. For all analysis significance level of $\alpha \leq .05$ or $\alpha \leq .01$ were assumed. The findings revealed no significant main effects for the four categories of retail format ('shopping mall', 'supermarket', 'department store' and 'category killer') $(\mathrm{F}=1.324 ; \mathrm{p}=0.326$, and $\mathrm{F}=3.009 ; \mathrm{p}=0.087$ ) for the variables male by age and female by age. However, with regards to the two categories of respondents (male by age and female by age) statistically significant main effects were found $(\mathrm{F}=28.677 ; \mathrm{p}=0.000$, and $\mathrm{F}=28.188 ; \mathrm{p}=0.000)$ for the study variables (four categories of retail format). The above results indicate that differences among male respondents in different age groups, and female respondents in different age groups were detected for their visit for shopping in different types of retail formats but type of retail formats could not establish significant difference in visit of respondents by their gender and age. Thus the null hypothesis $\mathbf{H}_{1 \mathbf{a}}$ is rejected that there is no association between shopping frequency in retail formats of customers based on their gender and age. But the null hypothesis $\mathbf{H}_{\mathbf{1 b}}$ is supported that there is no association between shopping frequency of customers based on their gender and age in four types of retail formats. Gender and age were more or less equally important factors in affecting store visits. Table-4 depicts four different groups of consumers. The study found that both male and female respondents below the age of 25 years and above 35 years are less associated to shopping malls and category killers. Supermarkets and department stores were more frequently visited by all the respondents in the age group of 25-45 years. Elderly respondents with more than 45 years of age were positioned almost equal in all types of retail formats but close to supermarkets, meaning that they did not have a strong preference for any specific retail format. 


\subsection{Segmentation Based on Gender, Marital Status and Retail Format}

Table-5 shows the frequency of respondents visiting various types of stores by gender and marital status. Again, a two-way ANOVA was performed to test the hypothesis whether the pattern of the respondents' store visits depended on demographic variables, gender and marital status. For all analysis significance level of $\alpha \leq .05$ or $\alpha \leq .01$ were assumed. The findings revealed no significant main effects for the four categories of retail format ('shopping mall', 'supermarket', 'department store' and 'category killer') $(\mathrm{F}=1.457 ; \mathrm{p}=0.382)$ for the variable male by marital status but significant main effects were found $(F=29.739 ; p=0.009)$ for the variable female by marital status. Further, with regards to the two categories of respondents (male by marital status and female by marital status) no statistically significant main effects were found $(\mathrm{F}=4.179 ; \mathrm{p}=0.133$, and $\mathrm{F}=2.571 ; \mathrm{p}=0.207$ ) for the study variables (four categories of retail format). The above results indicate that no differences among married and unmarried respondents were detected for their visit for shopping in different type of retail formats but type of retail formats were found significantly different in visit of female respondents by their marital status. Thus the null hypothesis $\mathbf{H}_{2 \mathbf{a}}$ is accepted that there is no association between shopping frequency in retail formats of customers based on their gender and marital status. But the null hypothesis $\mathbf{H}_{\mathbf{2 b}}$ is partially rejected that there is no association between shopping frequency of customers based on their gender and marital status in four types of retail formats.

Table 5: Cross-tabulation of Shopping Frequency by Gender and Marital Status $(\mathrm{N}=377)$

\begin{tabular}{|c|c|c|c|c|c|c|}
\hline $\begin{array}{l}\text { Gender and } \\
\text { Marital Status }\end{array}$ & $\begin{array}{l}\text { Shopping } \\
\text { Mall }\end{array}$ & Supermarket & $\begin{array}{l}\text { Department } \\
\text { Store }\end{array}$ & $\begin{array}{l}\text { Category } \\
\text { Killer }\end{array}$ & F Value & p value \\
\hline \multicolumn{5}{|l|}{ Male } & & \\
\hline Single & 56 & 39 & 53 & 51 & & \\
\hline Married & 78 & 61 & 46 & 74 & & \\
\hline \multicolumn{5}{|l|}{$F_{\text {row }}(1,3)$} & 4.179 & 0.133 \\
\hline \multicolumn{5}{|l|}{$F_{\text {column }}(\mathbf{3}, \mathbf{3})$} & 1.457 & 0.382 \\
\hline \multicolumn{5}{|l|}{ Female } & & \\
\hline Single & 54 & 35 & 58 & 54 & & \\
\hline Married & 61 & 39 & 61 & 52 & & \\
\hline \multicolumn{5}{|l|}{$F_{\text {row }}(1,3)$} & 2.571 & 0.207 \\
\hline \multicolumn{5}{|l|}{$F_{\text {column }}(\mathbf{3}, \mathbf{3})$} & 29.739 & $0.009 * *$ \\
\hline
\end{tabular}

Annotations: $* \mathrm{p} \leq .05 ; * \mathrm{*} \leq .01$; and $\mathrm{N}=$ Number of respondents

Gender and marital status were not observed important factors in affecting store visits. However, visits of retail customers showed significant differences based on type of retail stores. Table-5 depicts two different groups of consumers. No significant association based on gender and marital status of respondents was found with the four categories of retail format, meaning that they did not have a strong preference for any specific retail format. Though, married female respondents were more likely to visit shopping malls and department stores, followed by category killers and supermarkets, meaning that they have a stronger preference for visit to these retail formats as compared to their unmarried female counterparts. 


\subsection{Segmentation Based on Gender, Occupation and Retail Format}

Table-6 shows the frequency of respondents visiting various types of stores by gender and occupation. Again, a two-way ANOVA was performed to test the hypothesis whether the pattern of the respondents' store visits depended on demographic variables, gender and occupation. For all analysis significance level of $\alpha \leq .05$ or $\alpha \leq .01$ were assumed. The findings revealed no significant main effects for the four categories of retail format ('shopping mall', 'supermarket', 'department store' and 'category killer') $(\mathrm{F}=3.315 ; \mathrm{p}=0.099$, and $\mathrm{F}=1.926 ; \mathrm{p}=0.196)$ for the variables male by occupation and female by occupation. However, with regards to the two categories of respondents (male by occupation and female by occupation) statistically significant main effects were found $(\mathrm{F}=70.585 ; \mathrm{p}=0.000$, and $\mathrm{F}=49.388 ; \mathrm{p}=0.000)$ for the study variables (four categories of retail format). The above results indicate that differences among male respondents in different occupations, and female respondents in different occupations were detected for their visit for shopping in different type of retail formats but type of retail formats could not establish significant difference in visit of respondents by their gender and occupation. Thus the null hypothesis $\mathbf{H}_{\mathbf{3}}$ is rejected that there is no association between shopping frequency in retail formats of customers based on their gender and occupation. But the null hypothesis $\mathbf{H}_{\mathbf{3 b}}$ is accepted that there is no association between shopping frequency of customers based on their gender and occupation in four types of retail formats.

Table 6: Cross-tabulation of Shopping Frequency by Gender and Occupation $(\mathrm{N}=377)$

\begin{tabular}{|c|c|c|c|c|c|c|}
\hline $\begin{array}{l}\text { Gender } \\
\text { Occupation }\end{array}$ & $\begin{array}{l}\text { Shopping } \\
\text { Mall }\end{array}$ & Supermarket & $\begin{array}{l}\text { Department } \\
\text { Store }\end{array}$ & $\begin{array}{l}\text { Category } \\
\text { Killer }\end{array}$ & $\begin{array}{l}\mathbf{F} \\
\text { Value }\end{array}$ & $p$ value \\
\hline \multicolumn{5}{|c|}{ Male } & & \\
\hline Student & 14 & 7 & 9 & 11 & & \\
\hline Salaried & 57 & 46 & 43 & 46 & & \\
\hline Self-Business & 63 & 45 & 47 & 68 & & \\
\hline \multicolumn{5}{|l|}{$F_{\text {row }}(2,6)$} & 70.585 & $0.000 * *$ \\
\hline \multicolumn{5}{|l|}{$F_{\text {column }}(3,6)$} & 3.315 & 0.099 \\
\hline \multicolumn{5}{|l|}{ Female } & & \\
\hline Student & 4 & 2 & 3 & 3 & & \\
\hline Housewife & 13 & 11 & 8 & 7 & & \\
\hline Salaried & 64 & 43 & 76 & 59 & & \\
\hline Self-Business & 34 & 18 & 32 & 37 & & \\
\hline \multicolumn{5}{|l|}{$F_{\text {row }}(3,9)$} & 49.388 & $0.000 * *$ \\
\hline \multicolumn{5}{|l|}{$F_{\text {column }}(3,9)$} & 1.926 & 0.196 \\
\hline
\end{tabular}

Annotations: ${ }^{*} \mathrm{p} \leq .05 ; * * \mathrm{p} \leq .01$; and $\mathrm{N}=$ Number of respondents

Gender and occupation were more or less equally important factors in affecting store visits. Table- 6 depicts three different groups of male customers and four different groups of female customers. The study found that male who are self-employed preferred more visiting category killer stores as compared to salaried male respondents and surprisingly, on the contrary, female salaried respondents were more likely to visit not only the department store but all types of retail formats as compared to self-employed females. First preference of housewives was shopping mall, followed by supermarket, department store and category killer. 


\subsection{Segmentation on Gender, Educational Qualification and Retail Format}

Table-7 shows the frequency of respondents visiting various types of stores by gender and education. Again, a two-way ANOVA was performed to test the hypothesis whether the pattern of the respondents' store visits depended on demographic variables, gender and education. For all analysis significance level of $\alpha \leq .05$ or $\alpha \leq .01$ were assumed. The findings revealed no significant main effects for the four categories of retail formats ('shopping mall', 'supermarket', 'department store' and 'category killer') $(\mathrm{F}=2.948 ; \mathrm{p}=0.120$, and $\mathrm{F}=1.430 ; \mathrm{p}=0.324)$ for the variables male by education and female by education. However, with regards to the two categories of respondents (male by education and female by education) statistically significant main effects were found $(\mathrm{F}=51.300 ; \mathrm{p}=0.000$, and $\mathrm{F}=27.850 ; \mathrm{p}=0.000)$ for the study variables (four categories of retail formats). The above results indicate that differences among male respondents holding different educational qualification, and female respondents holding different educational qualification were detected for their visit for shopping in different type of retail formats but type of retail formats could not establish significant difference in visit of respondents by their gender and education. Thus the null hypothesis $\mathbf{H}_{\mathbf{4}}$ is rejected that there is no association between shopping frequency in retail formats of customers based on their gender and education. But the null hypothesis $\mathbf{H}_{\mathbf{4 b}}$ is supported that there is no association between shopping frequency of customers based on their gender and education in four types of retail formats.

Table 7: Cross-tabulation of Shopping Frequency by Gender and Educational Qualification $(\mathrm{N}=377)$

\begin{tabular}{|c|c|c|c|c|c|c|}
\hline $\begin{array}{l}\text { Gender } \\
\text { Educational } \\
\text { Qualification }\end{array}$ & $\begin{array}{l}\text { Shopping } \\
\text { Mall }\end{array}$ & Supermarket & $\begin{array}{l}\text { Department } \\
\text { Store }\end{array}$ & $\begin{array}{l}\text { Category } \\
\text { Killer }\end{array}$ & $\begin{array}{l}\text { F } \\
\text { Value }\end{array}$ & p value \\
\hline \multicolumn{5}{|l|}{ Male } & & \\
\hline Diploma or below & 19 & 13 & 8 & 9 & & \\
\hline Bachelor Degree & 54 & 41 & 39 & 61 & & \\
\hline $\begin{array}{l}\text { Master Degree or } \\
\text { above }\end{array}$ & 61 & 44 & 52 & 55 & & \\
\hline \multicolumn{5}{|l|}{$F_{\text {row }}(2,6)$} & 51.300 & $\mathbf{0 . 0 0 0}$ *** \\
\hline \multirow{2}{*}{\multicolumn{5}{|c|}{$\begin{array}{l}F_{\text {column }}(3,6) \\
\text { Female }\end{array}$}} & 2.948 & 0.120 \\
\hline & & & & & & \\
\hline Diploma or below & 8 & 2 & 5 & 3 & & \\
\hline Bachelor Degree & 57 & 29 & 48 & 61 & & \\
\hline $\begin{array}{l}\text { Master Degree or } \\
\text { above }\end{array}$ & 50 & 43 & 66 & 42 & & \\
\hline \multicolumn{5}{|l|}{$F_{\text {row }}(2,6)$} & 27.850 & $0.000 * *$ \\
\hline \multicolumn{5}{|l|}{$F_{\text {column }}(3,6)$} & 1.430 & 0.324 \\
\hline
\end{tabular}

Annotations: $* \mathrm{p} \leq .05 ; * * \mathrm{p} \leq .01$; and $\mathrm{N}=$ Number of respondents

Again, gender and education were found more or less equally important factors in affecting store visits. Table-7 depicts three different groups of consumers. Interestingly, the study found that more qualified customers preferred more visiting to all types of retail stores as compared to less qualified. 


\subsection{Segmentation Based on Gender, Income and Retail Format}

Table-8 shows the frequency of respondents visiting various types of stores by gender and income. Again, a two-way ANOVA was performed to test the hypothesis whether the pattern of the respondents' store visits depended on demographic variables, gender and income. For all analysis significance level of $\alpha \leq .05$ or $\alpha \leq .01$ were assumed. The findings revealed no significant main effects for the four categories of retail formats ('shopping mall', 'supermarket', 'department store' and 'category killer') $(\mathrm{F}=1.589 ; \mathrm{p}=0.288$, and $\mathrm{F}=2.765 ; \mathrm{p}=0.134)$ for the variables male by income and female by income. Also, with regards to the two categories of respondents (male by income and female by income) no statistically significant main effects were found $(\mathrm{F}=2.679 ; \mathrm{p}=0.147$, and $\mathrm{F}=2.604 ; \mathrm{p}=0.153)$ for the study variables (four categories of retail formats). The above results detect no significant differences among respondents by gender and income for their visit for shopping in different type of retail formats and also the type of retail formats could not establish significant difference in visit of respondents by their gender and income. Thus the null hypothesis $\mathbf{H}_{\mathbf{5}}$ is accepted that there is no association between shopping frequency in retail formats of customers based on their gender and income. Also, the null hypothesis $\mathbf{H}_{\mathbf{5 b}}$ is accepted that there is no association between shopping frequency of customers based on their gender and income in four types of retail formats.

Table 8: Cross-tabulation of Shopping Frequency by Gender and Annual Income (N=377)

\begin{tabular}{|c|c|c|c|c|c|c|}
\hline $\begin{array}{l}\text { Gender and } \\
\text { Income }\end{array}$ & $\begin{array}{l}\text { Shopping } \\
\text { Mall }\end{array}$ & Supermarket & $\begin{array}{l}\text { Department } \\
\text { Store }\end{array}$ & $\begin{array}{l}\text { Category } \\
\text { Killer }\end{array}$ & F Value & p value \\
\hline \multicolumn{5}{|l|}{ Male } & & \\
\hline$<$ Rupees 5 lakhs & 41 & 33 & 26 & 21 & & \\
\hline $\begin{array}{ll}\begin{array}{l}\text { Rupees } \\
\text { lakhs }\end{array} & 5-10 \\
\end{array}$ & 49 & 31 & 34 & 48 & & \\
\hline $\begin{array}{l}>\quad \text { Rupees } 10 \\
\text { lakhs }\end{array}$ & 44 & 34 & 39 & 56 & & \\
\hline \multicolumn{5}{|l|}{$F_{\text {row }}(2,6)$} & 2.679 & 0.147 \\
\hline \multicolumn{5}{|l|}{$F_{\text {column }}(3,6)$} & 1.589 & 0.288 \\
\hline \multicolumn{5}{|l|}{ Female } & & \\
\hline \begin{tabular}{ll|}
$<$ & Rupees 5 \\
lakhs &
\end{tabular} & 38 & 22 & 34 & 18 & & \\
\hline $\begin{array}{l}\begin{array}{l}\text { Rupees } \\
\text { lakhs }\end{array} \\
\end{array}$ & 36 & 29 & 41 & 41 & & \\
\hline $\begin{array}{l}>\quad \text { Rupees } 10 \\
\text { lakhs }\end{array}$ & 41 & 23 & 44 & 47 & & \\
\hline \multicolumn{5}{|l|}{$F_{\text {row }}(2,6)$} & 2.604 & 0.153 \\
\hline \multicolumn{5}{|l|}{$F_{\text {column }}(3,6)$} & 2.765 & 0.134 \\
\hline
\end{tabular}

Annotations: ${ }^{*} \mathrm{p} \leq .05 ; * * \mathrm{p} \leq .01$; and $\mathrm{N}=$ Number of respondents

Gender and income were not found important factors in affecting store visits. Table- 8 depicts three different groups of consumers. Surprisingly, the study did not find any significant association between the respondents belonging to different income groups and about their visits to different type of retail formats, meaning that all customers irrespective of their gender and level of income have equal preference for different retail formats. 


\subsection{Shopping Motives of Retail Customers}

Table-9 shows that considerable proportions of shoppers reported 'making a specific purchase' (47 out of 204 male and 39 out of 173 female respondents) 'bargain hunt' (24 out of 204 male and 41 out of 173 female respondents) and 'look and browse' (31 out of 204 male and 24 out of 173 female respondents) as the main reasons for their visit to the retail formats on the day they were surveyed. Thus, majority of male and female customers (102 out of 204 male and 104 out of 173 female respondents, respectively) visited the retail format for the three reasons combined, indicating that the retail formats in India are catering for the main purchasing needs of their consumers, whether window shopping or actual purchase or bargaining. However, the results of cross-tabulation indicate significant differences between the two groups. More male customers than female reported that they came with actual purchase intent or to look and browse, while approximately 23 per cent of the female customers came with a bargain haunting intent, compared to less than 11 per cent of the male customers. Interestingly, more male customers (30.88 per cent v/s 26.59 per cent) reported other reasons for their visit, including eating and meeting friends at the place of retail format. Also more male customers indicated 'shopping at a specific store' as a stronger reason as compared to the female counterparts. Based on their age, more respondents below 35 years reported 'eating' followed by 'making a specific purchase' and 'look and browse' than any other age group as the main reasons for their visit to the retail formats. The Chi-square $\left(\chi^{2}\right)$ test was used to test the significant differences in shopping motives of the respondents based on their gender and age. Results of the $\chi^{2}$ test as shown in table- 9 confirmed that there are significant differences in the shopping motives of male and female customers belonging to different age groups. Taken together, it seems that male customers and those below the age of 35 years tend to treat the retail format as a place for completing transactions, food consumption, and social gathering, while the female respondents and those above 35 years of age are more inclined to view the retail format simply as a place where business transactions are conducted.

Table 9: Cross-tabulation of Shopping Motives by Gender and Age $(N=377)$

\begin{tabular}{|c|c|c|c|c|c|c|c|}
\hline \multirow{2}{*}{ Shopping Motives } & \multicolumn{4}{|c|}{ Gender } & \multirow{2}{*}{$\begin{array}{l}\chi^{2} \\
\text { Value }\end{array}$} & \multirow{2}{*}{ df } & \multirow{2}{*}{$\begin{array}{l}\text { Asymp. Sig. } \\
\text { (two-sided) }\end{array}$} \\
\hline & \multicolumn{2}{|l|}{ Male } & \multicolumn{2}{|c|}{ Female } & & & \\
\hline $\begin{array}{l}\text { Look and browse/ Window } \\
\text { shopping }\end{array}$ & \multicolumn{2}{|l|}{31} & \multicolumn{2}{|l|}{24} & 0.891 & 1 & 0.345 \\
\hline Make a specific purchase & \multicolumn{2}{|l|}{47} & \multicolumn{2}{|l|}{39} & 0.744 & 1 & 0.388 \\
\hline Bargain hunt & \multicolumn{2}{|l|}{24} & \multicolumn{2}{|l|}{41} & 4.446 & 1 & $0.035 *$ \\
\hline Shopping at a specific store & \multicolumn{2}{|l|}{39} & \multicolumn{2}{|l|}{23} & 4.129 & 1 & $0.042 *$ \\
\hline Meet friends & \multicolumn{2}{|l|}{14} & \multicolumn{2}{|l|}{5} & 4.263 & 1 & 0.039* \\
\hline Eat & \multicolumn{2}{|l|}{49} & \multicolumn{2}{|l|}{41} & 0.711 & 1 & 0.399 \\
\hline \multirow[t]{3}{*}{ Total } & \multicolumn{2}{|l|}{204} & \multicolumn{2}{|l|}{173} & 12.721 & 5 & $0.026 *$ \\
\hline & \multicolumn{4}{|l|}{ Age } & & & \\
\hline & $\begin{array}{l}<25 \\
\text { Year } \\
\text { S }\end{array}$ & $\begin{array}{l}25- \\
35 \\
\text { Year } \\
\text { s }\end{array}$ & $\begin{array}{l}36- \\
45 \\
\text { Year } \\
\text { s }\end{array}$ & $\begin{array}{l}>45 \\
\text { Year } \\
\text { s }\end{array}$ & & & \\
\hline $\begin{array}{l}\text { Look and browse/ Window } \\
\text { shopping }\end{array}$ & 7 & 31 & 12 & 3 & 38.891 & 3 & $0.000 * * *$ \\
\hline Make a specific purchase & 8 & 34 & 28 & 18 & $\mathbf{1 6 . 1 4 0}$ & 3 & $0.001 * * *$ \\
\hline
\end{tabular}




\begin{tabular}{|l|l|l|l|l|l|l|l|}
\hline Bargain hunt & 3 & 18 & 21 & 23 & $\mathbf{1 5 . 1 8 5}$ & 3 & $\mathbf{0 . 0 0 1} * * *$ \\
\hline Shopping at a specific store & 5 & 29 & 24 & 4 & $\mathbf{3 2 . 0 6 5}$ & 3 & $\mathbf{0 . 0 0 0} * * *$ \\
\hline Meet friends & 4 & 10 & 4 & 1 & $\mathbf{0 9 . 0 0 0}$ & 3 & $\mathbf{0 . 0 2 9} *$ \\
\hline Eat & 17 & 41 & 17 & 15 & $\mathbf{2 0 . 4 0 0}$ & 3 & $\mathbf{0 . 0 0 0} * * *$ \\
\hline Total & $\mathbf{4 4}$ & $\mathbf{1 6 3}$ & $\mathbf{1 0 6}$ & $\mathbf{6 4}$ & $\mathbf{4 8 . 9 6 5}$ & 15 & $\mathbf{0 . 0 0 0} * * *$ \\
\hline
\end{tabular}

Annotations: ${ }^{*} p \leq .05$ (Asymp. Sig. (two-sided)); ${ }^{*} p \leq .01$ (Asymp. Sig. (two-sided)); ${ }^{* *} p \leq .001$ (Asymp. Sig. (two-sided)); $\mathrm{df}=$ Degree of freedom; and $\mathrm{N}=$ Number of respondents

\subsection{Companions of Retail Customers during Store Visit}

The respondents were asked to explain to whom as companion they consider during their visit to retail format. Majority of the male customers (81 out of 204 male v/s 54 out of 173 female respondents) and below the age group of 35 years prefer visiting with their friends whereas female customers (83 out of 173 female v/s. 74 out of 204 male respondents) and those above 35 years of age consider family as their companion (table-10).

Table 10: Cross-tabulation of Companions by Gender and Age $(N=377)$

\begin{tabular}{|c|c|c|c|c|c|c|c|}
\hline \multirow{2}{*}{ Companions } & \multicolumn{4}{|c|}{ Gender } & \multirow{2}{*}{$\begin{array}{l}\chi^{2} \\
\text { Value }\end{array}$} & \multirow{2}{*}{ df } & \multirow{2}{*}{$\begin{array}{l}\text { Asymp. Sig. } \\
\text { (two-sided) }\end{array}$} \\
\hline & \multicolumn{2}{|c|}{ Male } & \multicolumn{2}{|c|}{ Female } & & & \\
\hline Alone & \multicolumn{2}{|l|}{49} & \multicolumn{2}{|l|}{36} & 1.988 & 1 & 0.159 \\
\hline Family & \multicolumn{2}{|l|}{74} & \multicolumn{2}{|l|}{83} & 0.516 & 1 & 0.473 \\
\hline Friends & \multicolumn{2}{|l|}{81} & \multicolumn{2}{|l|}{54} & 5.4 & 1 & 0.020* \\
\hline \multirow[t]{3}{*}{ Total } & \multicolumn{2}{|l|}{204} & \multicolumn{2}{|l|}{173} & 5.392 & 2 & 0.067 \\
\hline & \multicolumn{4}{|l|}{ Age } & & & \\
\hline & $\begin{array}{l}<25 \\
\text { Years } \\
\end{array}$ & $\begin{array}{l}25-35 \\
\text { Years } \\
\end{array}$ & $\begin{array}{l}36-45 \\
\text { Years } \\
\end{array}$ & $\begin{array}{|lr|}>45 \\
\text { Years } \\
\end{array}$ & & & \\
\hline Alone & 9 & 40 & 22 & 14 & \begin{tabular}{|l|}
26.106 \\
\end{tabular} & 3 & $\mathbf{0 . 0 0 0} * * *$ \\
\hline Family & 7 & 57 & 55 & 38 & \begin{tabular}{|l|l|}
40.885 \\
\end{tabular} & 3 & $\mathbf{0 . 0 0 0} * * *$ \\
\hline Friends & 28 & 66 & 29 & 12 & \begin{tabular}{|l|}
46.481 \\
\end{tabular} & 3 & $0.000 * * *$ \\
\hline Total & 44 & 163 & 106 & 64 & 34.607 & 6 & $0.000 * * *$ \\
\hline
\end{tabular}

Annotations: ${ }^{*} p \leq .05$ (Asymp. Sig. (two-sided)); ${ }^{* *} p \leq .01$ (Asymp. Sig. (two-sided)); $* * * p \leq .001$ (Asymp. Sig. (two-sided)); df = Degree of freedom; and $\mathrm{N}=$ Number of respondents

The Chi-square $\left(\chi^{2}\right)$ test was used to test the significant differences in companion preferences of the respondents based on their gender and age. Results of the $\chi^{2}$ test as shown in table-10 confirmed that there are significant differences in the preference based on customers' age group. However, no significant difference was found in customers' consideration about the companion in retail format based on their gender, except preference for friends was more by male as compared to their female counterparts.

\subsection{Retail Customers' Shopping Trip}

Further, the respondents were asked to indicate whether the shopping trip was planned or not. Majority of the male customers (128 out of 204 male v/s 91 out of 173 female respondents) and those below the age group of 35 years reported the shopping trip unplanned whereas female customers (82 out of 173 female v/s 76 out of 204 male respondents) and those above 45 years of 
age indicated the trip as planned one. More pointedly, retail customers belonging to different age groups were rather dissimilar as compared to respondents based on their gender with respect to whether their purchases were planned or unplanned (table-11).

Table 11: Cross-tabulation of Shopping Trip by Gender and Age $(N=377)$

\begin{tabular}{|c|c|c|c|c|c|c|c|}
\hline \multirow{2}{*}{ Shopping Trip } & \multicolumn{4}{|c|}{ Gender } & \multirow{2}{*}{$\begin{array}{l}\chi^{2} \\
\text { Value }\end{array}$} & \multirow{2}{*}{ df } & \multirow{2}{*}{$\begin{array}{l}\text { Asymp. Sig. } \\
\text { (two-sided) }\end{array}$} \\
\hline & \multicolumn{2}{|l|}{ Male } & \multicolumn{2}{|c|}{ Female } & & & \\
\hline Planned & \multicolumn{2}{|l|}{76} & \multicolumn{2}{|l|}{82} & 0.228 & 1 & 0.633 \\
\hline Unplanned & \multicolumn{2}{|l|}{128} & \multicolumn{2}{|l|}{91} & 6.251 & 1 & 0.012* \\
\hline \multirow[t]{3}{*}{ Total } & 204 & & 173 & & 3.957 & 1 & $0.047 *$ \\
\hline & \multicolumn{4}{|l|}{ Age } & & & \\
\hline & $\begin{array}{l}<\quad 25 \\
\text { Years }\end{array}$ & $\begin{array}{l}\text { 25-35 } \\
\text { Years }\end{array}$ & $\begin{array}{l}\text { 36-45 } \\
\text { Years }\end{array}$ & $\begin{array}{l}>\quad 45 \\
\text { Years }\end{array}$ & & & \\
\hline Planned & 19 & 42 & 56 & 41 & \begin{tabular}{|l|l|}
17.747 \\
\end{tabular} & 3 & $0.000 * * *$ \\
\hline Unplanned & 25 & 121 & 50 & 23 & 115.155 & 3 & $0.000 * * * *$ \\
\hline Total & 44 & 163 & 106 & 64 & 35.57 & 6 & $0.000 * * *$ \\
\hline
\end{tabular}

Annotations: $* p \leq .05$ (Asymp. Sig. (two-sided)); **p $\leq .01$ (Asymp. Sig. (two-sided)); ***p $\leq .001$ (Asymp. Sig. (two-sided)); df = Degree of freedom; and $\mathrm{N}=$ Number of respondents

The Chi-square $\left(\chi^{2}\right)$ test was used to test the significant differences in shopping trip (planned or unplanned) of the respondents based on their gender and age. Results of the $\chi^{2}$ test as shown in table-11 confirmed that there are significant differences in making a shopping trip planned or unplanned based on customers' age group. However, no significant difference was found in customers' consideration about the shopping trip in retail format based on their gender, except for more unplanned shopping trips as reported by male respondents as compared to their female counterparts.

\subsection{Store Visit Frequency of Retail Customers}

Store Visit Frequency of the retail customers was also noted by the researcher. Table-12 shows that there were more respondents who visit once in a month and even once in a quarter.

Table 12: Cross-tabulation of Store Visit Frequency by Gender and Age ( $N=377)$

\begin{tabular}{|c|c|c|c|c|c|c|c|}
\hline \multirow[b]{2}{*}{ Store Visit Frequency } & \multicolumn{4}{|c|}{ Gender } & \multirow{2}{*}{$\begin{array}{l}\chi^{2} \\
\text { Value }\end{array}$} & \multirow[b]{2}{*}{ df } & \multirow{2}{*}{$\begin{array}{l}\text { Asymp. } \\
\text { Sig. } \\
\text { (two- } \\
\text { sided) }\end{array}$} \\
\hline & \multicolumn{2}{|l|}{ Male } & \multicolumn{2}{|c|}{ Female } & & & \\
\hline Once in a week & \multicolumn{2}{|l|}{36} & \multicolumn{2}{|l|}{29} & 0.12 & 1 & 0.729 \\
\hline Once in a month & \multicolumn{2}{|l|}{67} & \multicolumn{2}{|l|}{51} & 2.169 & 1 & 0.141 \\
\hline Once in a quarter & \multicolumn{2}{|l|}{101} & \multicolumn{2}{|l|}{93} & 0.33 & 1 & 0.566 \\
\hline \multirow[t]{3}{*}{ Total } & \multicolumn{2}{|l|}{204} & \multicolumn{2}{|l|}{173} & 0.709 & 2 & 0.702 \\
\hline & \multicolumn{4}{|l|}{ Age } & & & \\
\hline & $\begin{array}{l}<\quad 25 \\
\text { Years }\end{array}$ & $\begin{array}{l}25-35 \\
\text { Years }\end{array}$ & $\begin{array}{l}36-45 \\
\text { Years }\end{array}$ & $\begin{array}{l}>\quad 45 \\
\text { Years }\end{array}$ & & & \\
\hline Once in a week & 12 & 24 & 23 & 6 & 14.077 & 3 & $0.003 * *$ \\
\hline Once in a month & 15 & 46 & 38 & 19 & 22.542 & 3 & $0.000 * * *$ \\
\hline
\end{tabular}




\begin{tabular}{|l|l|l|l|l|l|l|l|}
\hline Once in a quarter & 17 & 93 & 45 & 39 & $\mathbf{6 3 . 4 0 2}$ & 3 & $\mathbf{0 . 0 0 0} * * *$ \\
\hline Total & $\mathbf{4 4}$ & $\mathbf{1 6 3}$ & $\mathbf{1 0 6}$ & $\mathbf{6 4}$ & $\mathbf{1 3 . 2 2 9}$ & 6 & $\mathbf{0 . 0 4 0} *$ \\
\hline
\end{tabular}

Annotations: ${ }^{*} p \leq .05$ (Asymp. Sig. (two-sided)); ${ }^{* * p} \leq .01$ (Asymp. Sig. (two-sided)); $* * * p \leq .001$ (Asymp. Sig. (two-sided)); df = Degree of freedom; and $\mathrm{N}=$ Number of respondents

Again, chi-square $\left(\chi^{2}\right)$ test was used to test the significant differences in store visit frequency of the respondents based on their gender and age. Results of the $\chi^{2}$ test as shown in table-12 confirmed that there are significant differences in making a store visit on customers' age group. However, no significant difference was found in customers' visit in retail format based on their gender.

\subsection{Staying Time in Retail Store}

Respondents were also asked to speak how much time they spent on shopping during their visit to retail formats. On applying $\chi^{2}$ test, the only significant difference based on gender was found for those who spent less than half an hour. More male customers (41 out of 204 male v/s 22 out of 173 female respondents) were spending less than an hour for shopping in the retail store (table13). Chi-square $\left(\chi^{2}\right)$ test was also used to test the significant differences in staying time of the respondents based on their age groups. Results of the $\chi^{2}$ test as shown in table-13 confirmed that there are significant differences in spending time in a store based on customers' age groups. Respondents below the age of 35 years were spending more than two hours whereas customers above thirty five years were more who reported to spend 1-2 hours in the retail stores where they visited.

Table 13: Cross-tabulation of Length of Stay by Gender and Age $(N=377)$

\begin{tabular}{|c|c|c|c|c|c|c|c|}
\hline \multirow{2}{*}{ Length of Stay } & \multicolumn{4}{|c|}{ Gender } & \multirow{2}{*}{$\begin{array}{l}\chi^{2} \\
\text { Value }\end{array}$} & \multirow{2}{*}{ df } & \multirow{2}{*}{$\begin{array}{l}\text { Asymp. } \\
\text { Sig. } \\
\text { (two-sided) }\end{array}$} \\
\hline & \multicolumn{2}{|l|}{ Male } & \multicolumn{2}{|c|}{ Female } & & & \\
\hline Less than an hour & \multicolumn{2}{|l|}{41} & \multicolumn{2}{|l|}{22} & 5.730 & 1 & $0.017 *$ \\
\hline 1-2 Hours & \multicolumn{2}{|l|}{72} & \multicolumn{2}{|l|}{63} & 0.600 & 1 & 0.439 \\
\hline More than 2 hours & \multicolumn{2}{|l|}{91} & \multicolumn{2}{|l|}{88} & 0.050 & 1 & 0.823 \\
\hline \multirow[t]{3}{*}{ Total } & \multicolumn{2}{|l|}{204} & \multicolumn{2}{|l|}{173} & 3.857 & 2 & 0.145 \\
\hline & \multicolumn{4}{|l|}{ Age } & & & \\
\hline & $\begin{array}{l}<25 \\
\text { years }\end{array}$ & $\begin{array}{l}25-35 \\
\text { Years }\end{array}$ & $\begin{array}{l}36-45 \\
\text { Years }\end{array}$ & $\begin{array}{l}>45 \\
\text { Years }\end{array}$ & & & \\
\hline Less than an hour & 6 & 20 & 24 & 13 & 11.984 & 3 & $0.007 * *$ \\
\hline 1-2 Hours & 13 & 34 & 48 & 40 & 19.933 & 3 & $0.000 * * *$ \\
\hline More than 2 hours & 25 & 109 & 34 & 11 & 129.000 & 3 & $0.000 * * *$ \\
\hline Total & 44 & 163 & 106 & 64 & 62.33 & 6 & $0.000 * * *$ \\
\hline
\end{tabular}

Annotations: ${ }^{*} p \leq .05$ (Asymp. Sig. (two-sided)); $* * p \leq .01$ (Asymp. Sig. (two-sided)); $* * * p \leq .001$ (Asymp. Sig. (two-sided)); df = Degree of freedom; and $\mathrm{N}=$ Number of respondents

\section{Conclusion}

Retailers must have an accurate analysis of their market segment i.e. who are the customers and how often they interact to different types of retail formats. Demographic determinants are important criteria in the first stage of structuring customer markets. The analysis (two-way 
analysis) revealed important insights into the demographic segments of each retail format based upon gender and age, marital status, income, education and occupation of consumers as well the retail format segments. The study concludes that gender and age, gender and occupation, and gender and education are more or less equally important factors whereas gender and marital status, and gender and income were not found important factors in affecting store visits. The study also concludes that retail customers share many behavioral patterns. First, their visits to the stores were primarily driven by purchase needs, either window shopping or making actual purchases followed by eating. Second, more people prefer to visit these stores along with their friends or family; this result contributes to that being accompanied by others (Companion), shoppers more likely to buy food and less likely to buy non-food products. Third, considerably bigger proportion of consumers visit to these stores in an unplanned way, their length of stay in the store is more, but visit frequency is low. However, many consumers who came with the intent to look and browse actually made purchases by the end of their trip; this result contributes to a bigger proportion of respondents spending more time make unplanned purchases during their shopping trips. This study investigated demographics factors only, scope of future study may include Psychographics factors (customers' thinking, feeling, reaction and reflection), and geographical factors such as distance and travelling time that may influence customers' interactions towards different type of retail formats.

\section{References}

[1] Bawa, K. and Ghosh, A. A model of household grocery shopping behaviour, Marketing Letters, 10(2), 1999, 149-60.

[2] Bellenger, D.N. and Korgaonkar, P.K. Profiling the recreational shopper, Journal of Retailing, 56(3), 1980, 77-92.

[3] Carpenter, M.J. and Moore, M. Consumer demographics, store attributes, and retail format choice in the US grocery market, International Journal of Retail \& Distribution Management, 34(6), 2006, 434-52.

[4] Carpenter, M.J. Demographics and patronage motives of super centre shoppers in the United States, USA International Journal of Retail \& Distribution Management 36(1), 2008, 5-16.

[5] Fox, E.J. Montgomery, A.L. and Lodish, L.M. Consumer shopping and spending across retail formats, Journal of Business, 77(2), 2004, 25-60.

[6] Guidry, K. and Montero, T. Lifestyle centres: the de-malling of consumerism, Real Estate Review, 34(1), 2005, 5-16.

[7] Lee, S., Ibrahim, M. and Hsueh-Shan, C. Shopping-centre attributes affecting male shopping behaviour, Journal of Retail and Leisure Property, 4(4), 2005, 324-40.

[8] Nunnally, J.C. Psychometric Theory, Second Edition, McGraw Hill, New York, 1978.

[9] Prasad, C.J. and Aryasri, A.R. Effect of shopper attributes on retail format choice behaviour for food and grocery retailing in India, International Journal of Retail \& Distribution Management, 39(1), 2011, 68-86.

[10] Sinha, P.K. Shopping orientation in the evolving Indian market, Vikalpa, 28(2), 2003, 13-22.

[11] Stone, K.E. Competing with the Retail Giants: How to Survive in the New Retail Landscape, Wiley, New York, NY, 1995.

[12] http://www.indiaonlinepages.com/population/india-current-population.html accessed on 10/07/2016.

*Corresponding author.

E-mail address: pankaj3950@yahoo.co.in 